\title{
Pengembangan Perangkat Pembelajaran Biologi Berorientasi Keterampilan Proses untuk Mengajarkan Life Skills Siswa
}

\author{
EKO SULISTIONO \\ Fakultas Teknik UNISLA \\ E-mail: eko.sulistiono86@gmail.com
}

\begin{abstract}
Abstrak:
Pembelajaran IPA di Indonesia selama ini masih banyak menggunakan cara yang konvensional yaitu ceramah, sehigga perlu diterapkannya suatu pendekatan belajar yang lebih mengutamakan pada proses belajar dari pada produk yaitu dengan pendekatan keterampilan proses. Oleh karena itu perlu dikembangkannya perangkat pembelajaran biologi yang berorientasi keterampilan proses yang sekaligus diorientasikan untuk mengajarkan kecakapan hidup (life skills) siswa. Life skills penting diajarkan karena dapat membekali peserta didik dalam menghadapi dan memecahkan problem hidup dan kehidupan. Tujuan dari penelitian ini adalah untuk mendeskripsikan kualitas perangkat pembelajaran, hasil uji coba perangkat pembelajaran untuk mengajarkan life skills melalui keterampilan proses. Metode penelitian yang digunakan merupakan jenis penelitian pengembangan. Hasil dari penelitian yag telah dilakukan ialah pelaksanaan pembelajaran biologi berorientasi keterampilan proses yang didukung oleh ketersediaan perangkat pembelajaran yang telah divalidasi oleh para pakar dapat mengajarkan life skills, pada siswa kelas VII SMP.
\end{abstract}

Kata Kunci: Pembelajaran IPA, Life Skills

\section{Pendahuluan}

Mata pelajaran biologi menekankan pada pemberian pengalaman belajar dan sikap ilmiah sebagai salah satu aspek penting kecakapan hidup (life skills). Kecakapan hidup (life skills) merupakan pengembangan diri untuk bertahan hidup, tumbuh, dan berkembang, memiliki kemampuan untuk berkomunikasi dan berhubungan baik secara individu, kelompok maupun melalui sistem dalam menghadapi situasi tertentu (Hopson dalam Puskur, 2006). Life skills tersebut dapat dilatihkan kepada siswa melalui kegiatan pembelajaran keterampilan proses.

Biologi sebagai salah satu bidang IPA menyediakan berbagai pengalaman belajar untuk memahami konsep dan proses sains. Pengalaman belajar itu meliputi keterampilan mengamati, mengajukan hipotesis, menggunakan alat dan bahan secara baik, mengajukan pertanyaan, menggolongkan dan menafsirkan data, mengkomunikasikan hasil temuan secara lisan atau tertulis. Mata pelajaran biologi dikembangkan melalui kemampuan berpikir analitis, induktif, dan deduktif untuk penyelesai- 
an masalah yang berkaitan

dengan 
peristiwa alam sekitar (Lampiran Permendiknas No 22 Tahun 2006).

Life skills yang harus dimiliki siswa adalah kecakapan berpikir (thinking skills), kecakapan sosial (social skills) dan kecakapan berpikir ilmiah (academic skills). Kecakapan berpikir (thinking skills) merupakan kecakapan menggali informasi, mengolah informasi, dan mengambil keputusan secara cerdas, serta mampu memecahkan masalah secara tepat dan baik. Kecakapan Sosial (social skills) dapat dipilah menjadi dua jenis, yaitu: (1) kecakapan berkomunikasi dan (2) kecakapan bekerjasama (Puskur, 2006). Kecakapan berpikir ilmiah (academic skills) seringkali disebut juga kecakapan intelektual atau kemampuan berpikir ilmiah yang pada dasarnya merupakan pengembangan dari kecakapan berpikir secara umum namun mengarah kepada kegiatan yang bersifat keilmuan. Kecakapan ini mencakup kecakapan mengidentifikasi variabel, menjelaskan hubungan suatu fenomena tertentu, merumuskan hipo-tesis, merancang dan melaksanakan penelitian. Untuk membangun kecakapankecakapan tersebut diperlu-kan pula sikap ilmiah, kritis, obyektif, dan transparan. Komponen-komponen tersebut merupakan komponen keterampilan proses, yang diharapkan dengan dilatihkannya keterampilan proses maka kecakapan hidup (life skills) dapat terpenuhi.

Berdasarkan skor yang diperoleh siswa Indonesia dalam mengerjakan soal- soal TIMSS (Third International Mathematics and Science Study), siswa Indonesia berada pada rangking 34 dari

45 negara untuk mata pelajaran Matematika dan rangking 36 dari 45 negara untuk pelajaran IPA. Butir-butir soal TIMSS didesain untuk mencerminkan pemikiran dan prioritas terkini dalam IPA. Skor ini menunjukkan bahwa proses pembelajaran IPA di Indonesia kurang berhasil (Team World Bank, 2008) (Rahayu, 2010). Pembelajar-an IPA di Indonesia selama ini masih banyak menggunakan cara yang konven-sional yaitu ceramah, oleh karena itu perlu diterapkannya suatu pendekatan belajar yang lebih mengutamakan pada proses belajar dari pada produk yaitu dengan pendekatan keterampilan proses. Oleh karena itu perlu dikembangkannya perangkat pembelajaran biologi yang berorientasi keterampilan proses yang sekaligus diorientasikan untuk mengajarkan kecakapan hidup (life skills) siswa. Life skills penting diajarkan karena dapat membekali peserta didik dalam menghadapi dan memecahkan problem hidup dan kehidupan, baik secara pribadi yang mandiri maupun sebagai warga masyarakat.

\section{Metode Penelitian}

Penelitian ini merupakan jenis penelitian pengembangan karena mengembangkan perangkat pembelajaran biologi SMP pada materi Pencemaran Lingkungan yang berorientasi keterampilan proses untuk mengajarkan kecakapan hidup (life skills) di SMP Negeri 1 Lamongan pada semester genap di kelas VII-H.

Penelitian ini terdiri dari 2 tahap, yaitu tahap pertama pengembangan perangkat pembelajaran, dan tahap kedua adalah uji coba perangkat pembelajaran di kelas dengan menggunakan rancangan penlitian pada saat pengambilan data dalam rangka uji coba I dan II, menggunakan rancangan OneGroup Pretest-Post test Design yang dikembangkan oleh Campbell dan Stanley (Arikunto,2006). 


\section{Hasil dan Pembahasan}

\section{Hasil Pengembangan dan Validasi Pakar}

Validasi yang dilakukan oleh pakar meliputi validasi terhadap silabus, Rencana Pelaksanaan Pembelajaran (RPP), Buku Ajar Siswa (BAS), Lembar

Kegiatan Siswa (LKS), dan Tes Hasil Belajar (THB). Validasi yang dilakukan oleh para pakar dan praktisi pendidikan terhadap silabus meliputi komponen

tujuan pembelajaran, kegiatan pembelajaran, waktu, alat dan bahan ajar, dan penilaian. Validasi RPP meliputi komponen tujuan pembelajaran, kegiatan pembelajaran, waktu, perangkat pembelajaran, dan bahasa. Validasi BAS meliputi komponen kelayakan isi, kebahasaan dan penyajian. Validasi LKS meliputi aspek petunjuk, kelayakan isi, keterampilan proses, prosedur dan pertanyaan. Validasi THB meliputi aspek materi, konstruksi dan bahasa.

\begin{tabular}{|c|c|c|c|c|c|c|}
\hline \multirow{2}{*}{$\begin{array}{l}\text { N } \\
\text { o. }\end{array}$} & \multirow{2}{*}{$\begin{array}{c}\text { Aspek } \\
\text { Penilaian }\end{array}$} & \multicolumn{3}{|c|}{$\begin{array}{c}\text { Skala } \\
\text { Penilaia } \\
\text { n }\end{array}$} & \multirow[t]{2}{*}{$\begin{array}{l}\text { Ra } \\
\text { ta- } \\
\text { rat } \\
\text { a }\end{array}$} & \multirow[t]{2}{*}{ Ket } \\
\hline & & \begin{tabular}{l|}
$\mathbf{V}$ \\
$\mathbf{1}$
\end{tabular} & $\begin{array}{l}V \\
2\end{array}$ & $\begin{array}{l}\mathrm{V} \\
3\end{array}$ & & \\
\hline \multicolumn{7}{|c|}{ TUJUAN PEMBELAJARAN } \\
\hline 1. & $\begin{array}{l}\text { Menuliskan } \\
\text { Kompetensi } \\
\text { Dasar (KD) }\end{array}$ & 5 & 5 & 5 & 5 & $\begin{array}{l}\text { Sangat } \\
\text { baik }\end{array}$ \\
\hline 2. & $\begin{array}{l}\text { Ketepatan } \\
\text { penjabaran } \\
\text { dari KD ke } \\
\text { indikator }\end{array}$ & 4 & 4 & 4 & 4 & Baik \\
\hline 3. & $\begin{array}{l}\text { Indikator yang } \\
\text { dikembangkan } \\
\text { mencakup } \\
\text { pendekatan } \\
\text { Keterampilan } \\
\text { Proses Sains } \\
\text { (KPS) }\end{array}$ & 5 & 5 & 5 & 5 & $\begin{array}{l}\text { Sangat } \\
\text { baik }\end{array}$ \\
\hline 4. & $\begin{array}{l}\text { Mengembangk } \\
\text { an indikator } \\
\text { Keterampilan } \\
\text { Proses Sains } \\
\text { (KPS) }\end{array}$ & 5 & 4 & 5 & 4,7 & $\begin{array}{l}\text { Sangat } \\
\text { baik }\end{array}$ \\
\hline 5. & $\begin{array}{l}\text { Kesesuaian } \\
\text { aspek } \\
\text { keterampilan } \\
\text { proses yang } \\
\text { diajarkan } \\
\text { dengan } \\
\text { indikator }\end{array}$ & 5 & 4 & 5 & 4,7 & $\begin{array}{l}\text { Sangat } \\
\text { baik }\end{array}$ \\
\hline
\end{tabular}

\begin{tabular}{|c|c|c|c|c|c|c|}
\hline \multirow{2}{*}{$\begin{array}{l}\mathbf{N} \\
\mathbf{o}\end{array}$} & \multirow{2}{*}{$\begin{array}{c}\text { Aspek } \\
\text { Penilaian }\end{array}$} & \multicolumn{3}{|c|}{$\begin{array}{c}\text { Skala } \\
\text { Penilaia } \\
\text { n }\end{array}$} & \multirow[t]{2}{*}{$\begin{array}{l}\text { Ra } \\
\text { ta- } \\
\text { rat } \\
\text { a }\end{array}$} & \multirow[t]{2}{*}{ Ket } \\
\hline & & $\begin{array}{l}\mathrm{V} \\
\mathbf{1}\end{array}$ & $\begin{array}{l}\mathrm{V} \\
2\end{array}$ & $\begin{array}{l}\mathrm{V} \\
3\end{array}$ & & \\
\hline 6. & $\begin{array}{l}\text { Ketepatan } \\
\text { perumusan } \\
\text { indicator }\end{array}$ & 4 & 4 & 4 & 4 & Baik \\
\hline 7. & $\begin{array}{l}\text { Kesesuaian } \\
\text { indikator } \\
\text { dengan } \\
\text { kegiatan } \\
\text { pembelajaran }\end{array}$ & 5 & 4 & 5 & 4,7 & $\begin{array}{l}\text { Sangat } \\
\text { baik }\end{array}$ \\
\hline 8. & $\begin{array}{l}\text { Kesesuaian } \\
\text { indikator } \\
\text { dengan jenis } \\
\text { penilaian }\end{array}$ & 5 & 4 & 5 & 4,7 & $\begin{array}{l}\text { Sangat } \\
\text { baik }\end{array}$ \\
\hline \multicolumn{6}{|c|}{ KEGIATAN PEMBELAJARAN } & \\
\hline 1. & $\begin{array}{l}\text { Kesesuaian } \\
\text { tujuan } \\
\text { pembelajaran } \\
\text { dengan } \\
\text { kegiatan } \\
\text { pembelajaran }\end{array}$ & 4 & 4 & 4 & 4 & Baik \\
\hline 2. & $\begin{array}{l}\text { Kegiatan } \\
\text { pembelajaran } \\
\text { yang } \\
\text { dikembangkan } \\
\text { melibatkan } \\
\text { pendekatan } \\
\text { Keterampilan } \\
\text { Proses Sains } \\
\text { (KPS) }\end{array}$ & 5 & 4 & 5 & 4,7 & $\begin{array}{c}\text { Sangat } \\
\text { baik }\end{array}$ \\
\hline \multicolumn{7}{|c|}{ WAKTU } \\
\hline 1. & $\begin{array}{l}\text { Kesesuaian } \\
\text { alokasi waktu } \\
\text { yang } \\
\text { digunakan }\end{array}$ & 4 & 4 & 4 & 4 & Baik \\
\hline \multicolumn{7}{|c|}{ ALAT DAN BAHAN AJAR } \\
\hline 1. & $\begin{array}{l}\text { Menuliskan } \\
\text { sumber } \\
\text { pelajaran }\end{array}$ & 5 & 5 & 5 & 5 & $\begin{array}{l}\text { Sang } \\
\text { at } \\
\text { baik }\end{array}$ \\
\hline \multicolumn{7}{|c|}{ PENILAIAN } \\
\hline 1. & $\begin{array}{l}\text { Kesesuaian } \\
\text { tujuan } \\
\text { pembelajaran } \\
\text { dengan jenis } \\
\text { penilaian }\end{array}$ & 5 & 4 & 4 & 4,3 & Baik \\
\hline 2. & $\begin{array}{l}\text { Jenis penilaian } \\
\text { mencakup } \\
\text { lembar } \\
\text { penilaian (LP): } \\
\text { Produk } \\
\text { Proses } \\
\text { Kecakapan } \\
\text { berpikir } \\
\text { Kecakapan } \\
\text { akademik } \\
\text { Afektif } \\
\text { Kecakapan } \\
\text { sosial }\end{array}$ & 4 & 4 & 4 & 4 & Baik \\
\hline
\end{tabular}

Tabel 1 Hasil Validasi Silabus 


\begin{tabular}{|c|c|c|c|c|c|c|}
\hline \multirow[t]{2}{*}{ No. } & \multirow[t]{2}{*}{ Aspek Penilaian } & \multicolumn{3}{|c|}{$\begin{array}{c}\text { Skala } \\
\text { Penilaia } \\
\mathbf{n} \\
\end{array}$} & \multirow{2}{*}{$\begin{array}{l}\text { Ra } \\
\text { ta- } \\
\text { rat } \\
\text { a }\end{array}$} & \multirow[t]{2}{*}{ Ket } \\
\hline & & $\begin{array}{l}\mathrm{V} \\
1\end{array}$ & \begin{tabular}{l|}
$V$ \\
2 \\
\end{tabular} & $\begin{array}{l}\mathrm{V} \\
3 \\
\end{array}$ & & \\
\hline \multicolumn{7}{|c|}{ TUJUAN PEMBELAJARAN } \\
\hline 1. & $\begin{array}{l}\text { Menuliskan } \\
\text { Kompetensi } \\
\text { Dasar (KD) }\end{array}$ & 5 & 5 & 5 & 5 & $\begin{array}{c}\text { Sangat } \\
\text { baik }\end{array}$ \\
\hline 2. & $\begin{array}{l}\text { Ketepatan } \\
\text { penjabaran dari } \\
\text { KD ke indicator }\end{array}$ & 5 & 5 & 4 & 4,3 & Baik \\
\hline 3. & $\begin{array}{l}\text { Indikator yang } \\
\text { dikembangkan } \\
\text { mencakup } \\
\text { pendekatan } \\
\text { Keterampilan } \\
\text { Proses Sains } \\
\text { (KPS) }\end{array}$ & 5 & 5 & 5 & 5 & $\begin{array}{c}\text { Sangat } \\
\text { baik }\end{array}$ \\
\hline 4. & $\begin{array}{l}\text { Ketepatan } \\
\text { penjabaran dari } \\
\text { indikator ke } \\
\text { tujuan } \\
\text { pembelajaran }\end{array}$ & 5 & 4 & 4 & 4,3 & Baik \\
\hline 5. & $\begin{array}{l}\text { Mengembangka } \\
\mathrm{n} \text { tujuan } \\
\text { pembelajaran } \\
\text { Keterampilan } \\
\text { Proses Sains } \\
\text { (KPS) }\end{array}$ & 5 & 4 & 4 & 4,3 & Baik \\
\hline 6. & $\begin{array}{l}\text { Ketepatan } \\
\text { perumusan } \\
\text { tujuan } \\
\text { pembelajaran }\end{array}$ & 4 & 4 & 4 & 4 & Baik \\
\hline 7. & $\begin{array}{l}\text { Operasional } \\
\text { rumusan tujuan } \\
\text { pembelajaran }\end{array}$ & 4 & 4 & 4 & 4 & Baik \\
\hline \multicolumn{7}{|c|}{ KEGIATAN PEMBELAJARAN } \\
\hline 1. & $\begin{array}{l}\text { Model yang } \\
\text { dipilih sesuai } \\
\text { dengan tujuan } \\
\text { pembelajaran }\end{array}$ & 4 & 5 & 5 & 4,7 & $\begin{array}{l}\text { Sangat } \\
\text { baik }\end{array}$ \\
\hline 2. & $\begin{array}{l}\text { Model yang } \\
\text { dipilih dapat } \\
\text { melatihkan } \\
\text { Keterampilan } \\
\text { Proses Sains } \\
\text { (KPS) }\end{array}$ & 5 & 5 & 5 & 5 & $\begin{array}{c}\text { Sangat } \\
\text { baik }\end{array}$ \\
\hline 3. & $\begin{array}{l}\text { Kegiatan } \\
\text { pembelajaran } \\
\text { yang } \\
\text { dikembangkan } \\
\text { melibatkan } \\
\text { pendekatan } \\
\text { Keterampilan } \\
\text { Proses Sains } \\
\text { (KPS) }\end{array}$ & 5 & 5 & 5 & 5 & $\begin{array}{c}\text { Sangat } \\
\text { baik }\end{array}$ \\
\hline 4. & $\begin{array}{l}\text { Fase-fase model } \\
\text { ditulis lengkap } \\
\text { dalam RPP dan } \\
\text { Fase-fase sintaks } \\
\text { memuat dengan } \\
\text { jelas peran guru } \\
\text { dan peran siswa }\end{array}$ & 5 & 5 & 5 & 5 & $\begin{array}{c}\text { Sangat } \\
\text { baik }\end{array}$ \\
\hline 5. & $\begin{array}{l}\text { Skenario RPP } \\
\text { ada komponen }\end{array}$ & 4 & 4 & 4 & 4 & Baik \\
\hline
\end{tabular}

\begin{tabular}{|c|c|c|c|c|c|c|}
\hline \multirow[t]{2}{*}{ No. } & \multirow[t]{2}{*}{ Aspek Penilaian } & \multicolumn{3}{|c|}{$\begin{array}{c}\text { Skala } \\
\text { Penilaia } \\
\text { n }\end{array}$} & \multirow{2}{*}{$\begin{array}{l}\text { Ra } \\
\text { ta- } \\
\text { rat } \\
\text { a }\end{array}$} & \multirow[t]{2}{*}{ Ket } \\
\hline & & $\begin{array}{l}\mathrm{V} \\
\mathbf{1}\end{array}$ & $\begin{array}{l}\mathrm{V} \\
2\end{array}$ & \begin{tabular}{|l|}
$\mathrm{V}$ \\
3
\end{tabular} & & \\
\hline & $\begin{array}{l}\text { life skills yang } \\
\text { diajarkan yaitu: } \\
\text { Thinking skills } \\
\text { Social skills } \\
\text { Academic skills }\end{array}$ & & & & & \\
\hline \multicolumn{7}{|c|}{ WAKTU } \\
\hline 1. & $\begin{array}{l}\text { Pembagian } \\
\text { waktu setiap } \\
\text { kegiatan/fase } \\
\text { dinyatakan } \\
\text { dengan jelas }\end{array}$ & 5 & 4 & 5 & 4,7 & $\begin{array}{c}\text { Sangat } \\
\text { baik }\end{array}$ \\
\hline 2. & $\begin{array}{l}\text { Kesesuaian } \\
\text { waktu setiap } \\
\text { fase/kegiatan }\end{array}$ & 4 & 3 & 4 & 3,7 & Baik \\
\hline \multicolumn{7}{|c|}{ PERANGKAT PEMBELAJARAN } \\
\hline 1. & $\begin{array}{l}\text { Lembar kegiatan } \\
\text { siswa } \\
\text { (Worksheet) } \\
\text { mencakup } \\
\text { pendekatan } \\
\text { Keterampilan } \\
\text { Proses Sains } \\
\text { (KPS) }\end{array}$ & 5 & 4 & 4 & 4,3 & Baik \\
\hline 2. & $\begin{array}{l}\text { Lembar kegiatan } \\
\text { siswa } \\
\text { (Worksheet) } \\
\text { menunjang } \\
\text { ketercapaian } \\
\text { tujuan } \\
\text { pembelajaran }\end{array}$ & 4 & 4 & 4 & 4 & Baik \\
\hline 3. & $\begin{array}{l}\text { Buku siswa } \\
\text { yang } \\
\text { dikembangkan } \\
\text { mencakup } \\
\text { pendekatan } \\
\text { Keterampilan } \\
\text { Proses Sains } \\
\text { (KPS) }\end{array}$ & 4 & 4 & 4 & 4 & Baik \\
\hline 4. & $\begin{array}{l}\text { Buku siswa } \\
\text { yang } \\
\text { dikembangkan } \\
\text { dan dipilih } \\
\text { menunjang } \\
\text { ketercapaian } \\
\text { tujuan } \\
\text { pembelajaran } \\
\end{array}$ & 4 & 3 & 4 & 3,7 & Baik \\
\hline 5. & $\begin{array}{l}\text { Media } \\
\text { menunjang } \\
\text { ketercapaian } \\
\text { tujuan } \\
\text { pembelajaran }\end{array}$ & 4 & 5 & 4 & 4,3 & Baik \\
\hline 6. & $\begin{array}{l}\text { Butir-butir soal } \\
\text { lembar penilaian } \\
\text { (LP) mencakup: } \\
\text { a. Produk } \\
\text { b. Proses } \\
\text { Kecakapan } \\
\text { berpikir } \\
\text { Kecakapan } \\
\text { akademik } \\
\text { c. Afektif }\end{array}$ & 4 & 5 & 5 & 4,7 & $\begin{array}{c}\text { Sangat } \\
\text { baik }\end{array}$ \\
\hline
\end{tabular}




\begin{tabular}{|c|c|c|c|c|c|c|}
\hline \multirow[t]{2}{*}{ No. } & \multirow[t]{2}{*}{ Aspek Penilaian } & \multicolumn{3}{|c|}{$\begin{array}{c}\text { Skala } \\
\text { Penilaia } \\
\text { n }\end{array}$} & \multirow{2}{*}{$\begin{array}{l}\text { Ra } \\
\text { ta- } \\
\text { rat } \\
\text { a }\end{array}$} & \multirow[t]{2}{*}{ Ket } \\
\hline & & $\begin{array}{l}\mathrm{V} \\
1\end{array}$ & $\begin{array}{l}\mathrm{V} \\
2\end{array}$ & $\begin{array}{l}\mathrm{V} \\
3\end{array}$ & & \\
\hline & $\begin{array}{l}\text { Kecakapan } \\
\text { sosial }\end{array}$ & & & & & \\
\hline 7. & $\begin{array}{l}\text { Butir-butir soal } \\
\text { lembar penilaian } \\
\text { (LP) sesuai } \\
\text { dengan tujuan } \\
\text { pembelajaran }\end{array}$ & 4 & 5 & 5 & 4,7 & $\begin{array}{c}\text { Sangat } \\
\text { baik }\end{array}$ \\
\hline 8. & $\begin{array}{l}\text { Buku siswa, } \\
\text { Worksheet, } \\
\text { media, dan LP } \\
\text { diskenariokan } \\
\text { penggunaanya } \\
\text { dalam RPP }\end{array}$ & 4 & 5 & 5 & 4,7 & $\begin{array}{c}\text { Sangat } \\
\text { baik }\end{array}$ \\
\hline \multicolumn{7}{|c|}{ BAHASA } \\
\hline 1. & $\begin{array}{l}\text { RPP } \\
\text { menggunakan } \\
\text { kaidah bahasa } \\
\text { Inggris yang } \\
\text { baik dan benar }\end{array}$ & 3 & 4 & 3 & 3,3 & $\begin{array}{c}\text { Cukup } \\
\text { baik }\end{array}$ \\
\hline 2. & $\begin{array}{l}\text { Buku Siswa, } \\
\text { LKS (Worksheet), } \\
\text { Media, LP } \\
\text { dengan } \\
\text { menggunakan } \\
\text { bahasa Inggris } \\
\text { yang baik dan } \\
\text { benar }\end{array}$ & 3 & 4 & 4 & 3,7 & Baik \\
\hline 3. & $\begin{array}{l}\text { Ketepatan } \\
\text { struktur kalimat }\end{array}$ & 4 & 4 & 4 & 4 & Baik \\
\hline 4. & $\begin{array}{l}\text { Kemutakhitran } \\
\text { daftar pustaka }\end{array}$ & 4 & 5 & 5 & 4,7 & $\begin{array}{c}\text { Sangat } \\
\text { baik }\end{array}$ \\
\hline
\end{tabular}

Tabel 2. Hasil Validasi Rencana Pelaksanaan Pembelajaran (RPP)

\begin{tabular}{|c|c|c|c|c|c|c|}
\hline \multirow{2}{*}{ No. } & \multirow{2}{*}{ Aspek Penilaian } & \multicolumn{3}{|c|}{$\begin{array}{c}\text { Penilaia } \\
\mathbf{n}\end{array}$} & \multirow{2}{*}{$\begin{array}{l}\text { Ra } \\
\text { ta- } \\
\text { rat } \\
\text { a }\end{array}$} & \multirow{2}{*}{ Ket } \\
\hline & & $\begin{array}{l}\mathbf{V} \\
\mathbf{1}\end{array}$ & $\begin{array}{l}\mathrm{V} \\
2\end{array}$ & $\begin{array}{l}\mathrm{V} \\
3\end{array}$ & & \\
\hline \multicolumn{7}{|c|}{ A. ASPEK PETUNJUK } \\
\hline 1. & $\begin{array}{l}\text { Petunjuk } \\
\text { dinyatakan } \\
\text { dengan jelas }\end{array}$ & 5 & 4 & 4 & 4,3 & Baik \\
\hline 3. & $\begin{array}{l}\text { Materi LKS sesuai } \\
\text { dengan tujuan } \\
\text { pembelajaran di } \\
\text { LKS dan RPP }\end{array}$ & 4 & 4 & 4 & 4 & Baik \\
\hline 4. & $\begin{array}{l}\text { Mencantumkan } \\
\text { Keterampilan } \\
\text { Proses Sains } \\
\text { (KPS) yang } \\
\text { dilatihkan } \\
\end{array}$ & 5 & 5 & 5 & 5 & $\begin{array}{c}\text { Sangat } \\
\text { baik }\end{array}$ \\
\hline \multicolumn{7}{|c|}{ B. KELAYAKAN ISI } \\
\hline 1. & Keluasan materi & 5 & 5 & 5 & 5 & $\begin{array}{l}\text { Sangat } \\
\text { baik }\end{array}$ \\
\hline 2. & $\begin{array}{l}\text { Kedalaman } \\
\text { materi }\end{array}$ & 5 & 4 & 5 & 4,7 & $\begin{array}{l}\text { Sangat } \\
\text { baik }\end{array}$ \\
\hline 3. & $\begin{array}{l}\text { Menekankan } \\
\text { pada penerapan- } \\
\text { penerapan dunia }\end{array}$ & 5 & 5 & 5 & 5 & $\begin{array}{l}\text { Sangat } \\
\text { baik }\end{array}$ \\
\hline
\end{tabular}

\begin{tabular}{|c|c|c|c|c|c|c|}
\hline \multirow{2}{*}{ No. } & \multirow{2}{*}{ Aspek Penilaian } & \multicolumn{3}{|c|}{$\begin{array}{c}\text { Penilaia } \\
\text { n }\end{array}$} & \multirow{2}{*}{$\begin{array}{l}\text { Ra } \\
\text { ta- } \\
\text { rat } \\
\text { a }\end{array}$} & \multirow{2}{*}{ Ket } \\
\hline & & $\begin{array}{l}\mathrm{V} \\
\mathbf{1}\end{array}$ & \begin{tabular}{|l|}
$\mathrm{V}$ \\
2 \\
\end{tabular} & $\begin{array}{l}\mathrm{V} \\
3\end{array}$ & & \\
\hline & $\begin{array}{l}\text { nyata atau } \\
\text { kehidupan } \\
\text { sehari-hari } \\
\text { kecakapan } \\
\text { berpikir }\end{array}$ & & & & & \\
\hline 4. & $\begin{array}{l}\text { Menumbuhkan } \\
\text { rasa ingin tahu }\end{array}$ & 4 & 5 & 5 & 4,7 & $\begin{array}{c}\text { Sangat } \\
\text { baik }\end{array}$ \\
\hline 5. & $\begin{array}{l}\text { Mengembangkan } \\
\text { kecakapan sosial }\end{array}$ & 5 & 5 & 5 & 5 & $\begin{array}{c}\begin{array}{c}\text { Sangat } \\
\text { baik }\end{array} \\
\end{array}$ \\
\hline 6. & $\begin{array}{l}\text { Mengembangkan } \\
\text { kecakapan } \\
\text { akademik }\end{array}$ & 5 & 5 & 5 & 5 & $\begin{array}{c}\text { Sangat } \\
\text { baik }\end{array}$ \\
\hline 7 & $\begin{array}{l}\text { Menunjang } \\
\text { terlaksananya } \\
\text { proses belajar } \\
\text { mengajar yang } \\
\text { lebih diwarnai } \\
\text { oleh student } \\
\text { centered daripada } \\
\text { teacher centered }\end{array}$ & 4 & 5 & 5 & 4,7 & $\begin{array}{c}\text { Sangat } \\
\text { baik }\end{array}$ \\
\hline 8. & $\begin{array}{l}\text { Mendorong } \\
\text { untuk mencari } \\
\text { informasi lebih } \\
\text { lanjut }\end{array}$ & 3 & 3 & 3 & 3 & $\begin{array}{c}\text { Cukup } \\
\text { baik }\end{array}$ \\
\hline \multicolumn{7}{|c|}{ C. KETERAMPILAN PROSES SAINS (KPS) } \\
\hline 1. & $\begin{array}{l}\text { Melatihkan } \\
\text { Keterampilan } \\
\text { Proses Sains } \\
\text { (KPS) yang } \\
\text { dicantumkan } \\
\text { dalam tujuan } \\
\text { pembelajaran. }\end{array}$ & 4 & 5 & 5 & 4,7 & $\begin{array}{c}\text { Sangat } \\
\text { baik }\end{array}$ \\
\hline 2. & $\begin{array}{l}\text { Melatihkan } \\
\text { Keterampilan } \\
\text { Proses Sains } \\
\text { (KPS) yang } \\
\text { tercantum dalam } \\
\text { kegiatan LKS. }\end{array}$ & 5 & 5 & 5 & 5 & $\begin{array}{c}\text { Sangat } \\
\text { baik }\end{array}$ \\
\hline \multicolumn{7}{|c|}{ D. PROSEDUR } \\
\hline 1. & Urutan kerja & 4 & 4 & 4 & 4 & Baik \\
\hline 2. & $\begin{array}{l}\text { Keterbacaan/bah } \\
\text { asa dari prosedur }\end{array}$ & 4 & 4 & 4 & 4 & Baik \\
\hline \multicolumn{7}{|c|}{ E. PERTANYAAN } \\
\hline 1. & $\begin{array}{l}\text { Kesesuaian } \\
\text { pertanyaan } \\
\text { dengan tujuan } \\
\text { pembelajaran di } \\
\text { LKS dan RPP } \\
\end{array}$ & 4 & 4 & 4 & 4 & Baik \\
\hline 2. & $\begin{array}{l}\text { Pertanyaan } \\
\text { mendukung } \\
\text { konsep }\end{array}$ & 4 & 4 & 4 & 4 & Baik \\
\hline 3. & $\begin{array}{l}\text { Keterbacaan/bah } \\
\text { asa dari } \\
\text { pertanyaan }\end{array}$ & 4 & 4 & 4 & 4 & Baik \\
\hline
\end{tabular}

Tabel 3 Hasil Validasi Lembar Kegiatan Siswa (LKS) 


\begin{tabular}{|c|c|c|c|c|c|c|}
\hline \multirow{2}{*}{ No } & \multirow{2}{*}{$\begin{array}{ll}\begin{array}{l}\text { Aspek } \\
\text { dinilai }\end{array} & \text { yang } \\
\end{array}$} & \multicolumn{3}{|c|}{ Skala Penilaian } & \multirow{2}{*}{$\begin{array}{l}\text { Rata- } \\
\text { rata }\end{array}$} & \multirow{2}{*}{ Keterangan } \\
\hline & & V1 & $\mathrm{V} 2$ & V3 & & \\
\hline A & \multicolumn{6}{|c|}{ Aspek materi } \\
\hline 1 & $\begin{array}{l}\text { Butir tes sesuai } \\
\text { dengan } \\
\text { indicator }\end{array}$ & 4 & 4 & 4 & 4 & Baik \\
\hline 2 & $\begin{array}{l}\text { Batasan } \\
\text { pertanyaan dan } \\
\text { jawaban jelas }\end{array}$ & 3 & 4 & 4 & 3,7 & Baik \\
\hline 3 & $\begin{array}{l}\text { Isi materi sesuai } \\
\text { dengan tujuan } \\
\text { pengukuran }\end{array}$ & 4 & 4 & 4 & 4 & Baik \\
\hline 4 & $\begin{array}{l}\text { Isi materi sesuai } \\
\text { dengan jenjang } \\
\text { sekolah }\end{array}$ & 4 & 4 & 4 & 4 & Baik \\
\hline B & \multicolumn{6}{|c|}{ Aspek Konstruktif } \\
\hline 1 & $\begin{array}{l}\text { Rumusan } \\
\text { kalimat dalam } \\
\text { bentuk kalimat } \\
\text { Tanya atau } \\
\text { perintah yang } \\
\text { menuntut } \\
\text { jawabanterurai }\end{array}$ & 4 & 3 & 4 & 3,7 & Baik \\
\hline 2 & $\begin{array}{l}\text { Ada pedoman } \\
\text { penskoran }\end{array}$ & 4 & 4 & 4 & 4 & Baik \\
\hline $\mathrm{C}$ & \multicolumn{6}{|l|}{ Aspek Bahasa } \\
\hline 1 & $\begin{array}{l}\text { Rumusan } \\
\text { kalimat } \\
\text { komunikatif }\end{array}$ & 5 & 4 & 5 & 4,7 & Sangat baik \\
\hline 2 & $\begin{array}{l}\text { Kalimat } \\
\text { menggunakan } \\
\text { bahasa yang } \\
\text { baik dan benar }\end{array}$ & 4 & 4 & 4 & 4 & Baik \\
\hline 3 & $\begin{array}{l}\text { Rumusan } \\
\text { kalimat tidak } \\
\text { menimbulkan } \\
\text { penafsiran } \\
\text { ganda dan salah } \\
\text { pengertian }\end{array}$ & 4 & 4 & 4 & 4 & Baik \\
\hline 4 & $\begin{array}{l}\text { Menggunakan } \\
\text { bahasa atau } \\
\text { kata yang } \\
\text { umum(bukan } \\
\text { bahasalokal) }\end{array}$ & 5 & 5 & 5 & 5 & Sangat baik \\
\hline 5 & $\begin{array}{l}\text { Rumusan soal } \\
\text { tidak } \\
\text { mengandung } \\
\text { kata-kata yang } \\
\text { menyinggung } \\
\text { perasaan }\end{array}$ & 4 & 4 & 4 & 4 & Baik \\
\hline
\end{tabular}

Tabel 4 Hasil Validasi Tes Hasil Belajar Proses

\begin{tabular}{|c|l|l|}
\hline No & Aspek yang dinilai & Kategori \\
\hline 1 & Pendahuluan & Baik \\
\hline 2 & Inti & Baik \\
\hline 3 & Penutup & Baik \\
\hline \multicolumn{2}{|c|}{ Tabel 5 Hasil Pengamatan Keterlaksanaan } \\
Pembelajaran Berorientasi Keterampilan Proses \\
Untuk Mengajarkan Life Skills
\end{tabular}

\begin{tabular}{|c|c|c|c|c|}
\hline \multirow{3}{*}{ wa ${ }^{\text {Sis }}$} & \multicolumn{4}{|c|}{ Uji coba } \\
\hline & \multicolumn{2}{|l|}{ Nilai } & \multicolumn{2}{|c|}{ Ketuntasan } \\
\hline & Pretest & $t$ Postes & $\begin{array}{ll} & \text { Pretes } \\
t & \end{array}$ & t Postes \\
\hline 1 & 40 & 80 & TT & $\mathrm{T}$ \\
\hline 2 & 37 & 80 & TT & $\mathrm{T}$ \\
\hline 3 & 43 & 80 & TT & $\mathrm{T}$ \\
\hline 4 & 40 & 80 & TT & $\mathrm{T}$ \\
\hline 5 & 45 & 90 & TT & $\mathrm{T}$ \\
\hline 6 & 35 & 78 & TT & $\mathrm{T}$ \\
\hline 7 & 40 & 80 & TT & $\mathrm{T}$ \\
\hline 8 & 40 & 82 & TT & $\mathrm{T}$ \\
\hline 9 & 50 & 90 & TT & $\mathrm{T}$ \\
\hline 10 & 40 & 80 & TT & $\mathrm{T}$ \\
\hline 11 & 37 & 78 & TT & $\mathrm{T}$ \\
\hline 12 & 37 & 80 & TT & $\mathrm{T}$ \\
\hline 13 & 43 & 80 & TT & $\mathrm{T}$ \\
\hline 14 & 40 & 80 & TT & $\mathrm{T}$ \\
\hline 15 & 35 & 72 & TT & TT \\
\hline 16 & 40 & 80 & TT & $\mathrm{T}$ \\
\hline 17 & 37 & 78 & TT & $\mathrm{T}$ \\
\hline 18 & 40 & 80 & TT & $\mathrm{T}$ \\
\hline 19 & 40 & 80 & TT & $\mathrm{T}$ \\
\hline 20 & 35 & 70 & TT & TT \\
\hline 21 & 43 & 80 & TT & $\mathrm{T}$ \\
\hline 22 & 40 & 80 & TT & $\mathrm{T}$ \\
\hline 23 & 41 & 80 & TT & $\mathrm{T}$ \\
\hline 24 & 39 & 78 & TT & $\mathrm{T}$ \\
\hline 25 & 37 & 78 & TT & $\mathrm{T}$ \\
\hline 26 & 43 & 80 & TT & $\mathrm{T}$ \\
\hline 27 & 40 & 80 & TT & $\mathrm{T}$ \\
\hline 28 & 43 & 90 & TT & $\mathrm{T}$ \\
\hline 29 & 37 & 78 & TT & $\mathrm{T}$ \\
\hline 30 & 40 & 80 & TT & $\mathrm{T}$ \\
\hline${ }_{-} \mathrm{X}$ & 41,1 & 80,1 & & \\
\hline
\end{tabular}

Tabel 6 Daftar Nilai dan Ketuntasan hasil Belajar Produk

\begin{tabular}{|r|l|l|l|l|l|l|l|}
\hline \multirow{2}{*}{$\begin{array}{l}\text { No } \\
\text { T.P }\end{array}$} & $\begin{array}{l}\text { Nomor } \\
\text { Soal }\end{array}$ & $\begin{array}{l}\text { Ranah } \\
\text { Kognit } \\
\text { if }\end{array}$ & $\begin{array}{l}\text { Rata-rata } \\
\text { nilai Siswa } \\
\text { pada Uji } \\
\text { Coba 2 }\end{array}$ & \multicolumn{2}{l|}{$\begin{array}{l}\text { Presentase } \\
\text { Ketuntasan }\end{array}$} \\
\cline { 2 - 7 } & $\begin{array}{l}\text { Pre } \\
\text { test }\end{array}$ & $\begin{array}{l}\text { Pos } \\
\text { Test }\end{array}$ & $\begin{array}{l}\text { Pre } \\
\text { test }\end{array}$ & $\begin{array}{l}\text { Pos } \\
\text { test }\end{array}$ \\
\hline \multicolumn{7}{|c|}{ Thingking skill } \\
\hline 1 & 1 & C5 & 10 & 16 & 50 & 80 \\
\hline 1 & 2 & C6 & 12 & 25 & 40 & 83 \\
\hline 1 & 3 & C6 & 6 & 13 & 40 & 87 \\
\hline 2 & 4 & C5 & 6 & 10 & 46 & 84 \\
\hline 3 & 5 & C4 & 7 & 12 & 50 & 86 \\
\hline 4 & 6 & C4 & 4 & 9 & 40 & 90 \\
\hline 5 & 7 & C4 & 10 & 18 & 50 & 90 \\
\hline 6 & 8 & C5 & 6 & 13 & 40 & 85 \\
\hline Academic skill & \multicolumn{7}{|l|}{} \\
\hline 1 & 9 & C6 & 10 & 25 & 33 & 86 \\
\hline
\end{tabular}


Eko Sulistiono - Pengembangan Perangkat Pembelajaran Biologi Berorientasi Keterampilan Proses Tahol 7 Rokanitulaci Nilai-Thinkinoskillsdan

Academic Skills Siswa setelah Pembelajaran

Biologi Berorientasi Keterampilan Proses 


\section{Pembahasan}

Dalam memngembangkan perangkat pembelajaran berorientasi keterampilan proses untuk mengajarkan life skills peneliti melakukan validasi perangkat yang melibatkan para pakar di bidang biologi dan pendidikan serta praktisi. Perangkat pembelajaran yang dikembangkan dan digunakan, terdiri dari silabus, RPP, Buku Siswa, LKS dan Tes Hasil Belajar. Berdasarkan hasil validasi dan revisi yang telah dilakukan maka, RPP berorientasi pada keterampilan proses yang disusun dapat digunakan dengan layak untuk mengajarkan life skills (thinking skills, academic skills dan social skills) pada siswa kelas.

Tes hasil belajar proses digunakan untuk menilai thinking skills dan academic skills siswa setelah pembelajaran berlangsung. Tes hasil belajar proses diberikan dalam bentuk soal essay. Tujuan pembelajaran pada tes proses ini mencakup aspek thinking skills dan aspek academic skills.

Butir soal yang dipakai memiliki sensitivitas butir soal 0,4-0,6. Menurut Aiken bahwa nilai atau harga sensitivitas $>0,3$ menunjukkan sensitivitas yang baik. Tercapainya ketuntasan hasil belajar proses yang berorientasi thinking skills dan academic skills mengindikasikan bahwa pembelajaran berorientasi keterampilan proses dapat melatihkan life skills pada siswa. Pembelajaran dengan pendekatan keterampilan proses, memberikan kesempatan kepada siswa untuk berinteraksi langsung menggunakan alat-alat percobaan. Siswa mendapatkan pengalaman belajar cara menggunakan alat percobaan sehingga life skills siswa dapat terlatih dan dapat menggunakan alat percobaan dengan benar.

Prinsip pembelajaran kecakapan hidup (life skills) lebih kepada pembelajaran kontekstual, yaitu adanya keterkaitan antara kehidupan nyata dengan lingkungan dan pengalaman siswa, begitu pula pembelajaran dengan pendekatan keterampilan proses. Ada berbagai keterampilan dalam keterampilan proses, keterampilan-keterampilan tersebut terdiri dari keterampilanketerampilan dasar (basic skills) dan keterampilan-keterampilan terintegrasi (intregated skills). Keterampilan-keterampilan dasar terdiri dari enam keterampilan, yakni: mengobservasi, mengklasifikasi, memprediksi, mengukur, menyimpulkan, dan mengkomunikasikan. Sedangkan keterampilan-keterampilan terintegrasi terdiri dari: mengidentifikasi variabel, membuat tabulasi data, menyajikan data dalam bentuk grafik, menggambarkan hubungan antar variabel, mengumpulkan dan mengolah data, menganalisa penelitian, menyusun hipotesis, mendefinisikan variabel secara operasional, merancang penelitian, dan melaksanakan eksperimen (Funk, 1985 dalam Dimyati, 2002). Keterampilanketerampilan tersebut dapat sekaligus melatihkan life skills siswa.

Kecakapan berpikir (thinking skills) merupakan kecakapan dalam menggunakan rasio atau pikiran, yang mencakup antara lain: kecakapan mengenali dan menemukan informasi, mengolah dan mengambil keputusan, serta memecahkan masalah secara kreatif. Kecakapan akademik sering disebut juga kecakapan intelektual atau kemampuan berpikir ilmiah yang pada dasarnya merupakan pengembangan dari kecakapan berpikir secara umum, namun mengarah kepada kegiatan yang bersifat keilmuan. Kecakapan ini mencakup antara lain: kecakapan mengidentifikasi variabel, menjelaskan hubungan suatu fenomena tertentu, merumuskan hipotesis, merancang dan melaksanakan 
penelitian. Kecakapan-kecakapan tersebut merupakan keterampilan-keterampilan terintegrasi dalam keterampilan proses, hal ini sesuai dengan kemampuan dan konsep-konsep fundamental yang melandasi sain sebagai keterampilan proses.

\section{Kesimpulan}

Sesuai dengan hasil yang telah dijabarkan di atas, maka dapat disimpulkan bahwa pelaksanaan pembelajaran biologi berorientasi kete-rampilan proses yang didukung oleh ketersediaan perangkat pembelajaran yang telah divalidasi oleh para pakar dapat mengajarkan life skills, pada siswa kelas VII SMP.

\section{Daftar Pustaka}

Abruscato, J. 1992. Teaching Children Science 3th Edition. USA: Allyn and Bacon

Assaraf, O.B.Z dan Nir, O. 2005. "Development of System Thinking Skills in the". Journal of Research in Science Teaching. Vol. 42, No. 5, pp. 518-560.

Borich, G. D. 1990. Observation Skills for Effective Teaching. USA: Macmilan Publishing Company.

Brent, R. and Richard M.F. 2007. Cooperative Learning. "Journal Active Learning". Symposium Series, Chapter 4, pp. 34-53.

BSNP. 2006. Panduan Penyusunan Kurikulum Tingkat Satuan Pendidikan Jenjang Pendidikan Dasar dan Menengah. Jakarta: Badan Standar Nasional Pendidikan.

BSNP. 2006. Standar Isi untuk Satuan Pendidikan Dasar dan Menengah (Standar Kompetensi dan Kompetensi
Dasar). Jakarta: Badan Standar Nasional Pendidikan

Carin, A. A. 1993. Teaching Modern Science. New York: Macmillan Publishing Company.

Costa, A.L. 1988. Developing Minds.

Virginia: ASCD.

Creswell, J.W. 2008. Educational Research (Planing, Conducting and Evaluating Qualitative and Quantitative Research). USA: Pearson.

Davar, S.C. and Narendra, S. 2004. "Noise Pollution-Sources, Effects and Control". Journal Hum. Ecol. Vol. 16, No. 3. Pp. 181-187.

Dewi, S. 2008. Keterampilan Proses Sains.

Bandung: Tinta Emas.

Dick, W. and Lou, C. 1990. The Systematic Design of Instruction. Florida State: Haper Collins Publishers.

DITPSMP. 2011. Standar Kompeteensi Lulusan. Jakarta: Direktorat Jendral Pendidikan Dasar dan Menengah.

DITPSMP. 2004. SAINS. Jakarta:

Direktorat Jendral Pendidikan Dasar dan Menengah.

DITPSMP. 2005. Ilmu Pengetahuan Alam. Jakarta: Direktorat Jendral Pendidikan Dasar dan Menengah.

Duda, H.J. 2010. "Pembelajaran Berbasis Praktikum dan Asessmenya pada Konsep Sistem Ekskresi untuk Meningkatkan Berfikir Kritis Siswa Kelas XI". Jurnal VOX Edukasi, Vol. 1 No. 2, pp. 29-39.

Eggen, P. dan Don K. 2012. Strategre and Models for Teacher Sixth Edition. Boston: Pearson. 
2007." Cooperative Learning". Journal of Active Learning. Chapter 4, pp.3435.

Glencoe. Reading Essentials for Biology the Dinamic of Life. New York: Mc Graw Hill 
Glencoe. 1997. Life Science. New York: McGraw-Hill.

Glencoe. 2004. Biology the Dynamic of Life.

New York: McGraw-Hill.

Grinnel, J.R. and Richard, M. 1998. Social Work Research and Education Third Edition. Canada: Peacock Publisher, inc.

Gronlund, N.E. and Robert, L.L. 1995. Measurement and assessment in Teaching 7th Edition. USA: Prenticehall, Inc.

Harrison, M.R. 2001. Pollution, Causs, Effect and Control, 4 th edition. UK: Bookeraft Ltd.

Holdgate, M.W. 1980. A Perspective of Environmental Pollution. USA: Cambridge University Press.

Jhonson, D.W. dan Jhonson, R.T. 2002. Meaningful Assessment. USA: Allyn \& Bacon.

Lutfi, A. 2004. Kimia Lingkungan. Jakarta: Ditpsmk.

Martin, R.E.J. Colleen, S., Kay, W. and Jack, G. 1994. Teaching Science or All Children. USA: allyn and Bacon

Mcmurray M.A. and Paul B. 1991. "Realibility and Concrurrent validity of a Measure of Critical Thinking Skills in Biology". Journal of Research in Science Teaching. Vol.28, No.3, pp.183-192.

Mukono, H.J. 2008. Pencemaran Udara dan Pengaruhnya terhadap Gangguan Pernafasan. Surabaya: Airlangga university press.

Mulyasa, E. 2006. Kurikulum Tingkat Satuan Pendidikan (KTSP). Bandung: Rosda karya
Ngang, T.K. and Subadrah, N. 2012. "Exploring Parents and Teachers View of Primary Pupils Thinking Skills and Problem Solving Skills". Journal of Creative Education. Vol. 3, No. 1,

pp. 30-36. 
Proses Sains. Surabaya: PSMS.

Onwuegbuzie, A.J., Kathleen, M.T.C. and

Qun, G.J. 2009. "Performance of Cooperative Learning Groups in a Postgraduate Education Research Methodology Course". Journal of Active Learning in Higher Education. USA. Vol. 10, No. 3, pp. 65-277.

Slavin, R.E. 2006. Educational Psychology Theory and practice Eight Edition. USA:Library of congres Cataloging in Publication Data.

Slavin, R.E. 2011. Psikologi Pendidikan Teori dan Praktik Edisi ke-9. Jakarta: Indeks

Solomon, E.P., Berg, L.R. and Martin, D.W. 2008. Biology 8th Edition. Canada: Thomson.

Subratha, N. 1997. "Hasil Intensifikasi Pendekatan Keterampilan Proses dalam Pembelajaran IPA SD di Singaraja". Jurnal Aneka Widiya, No. 3, pp.148-156.

Suharsimi, A. 2006. Dasar-Dasar Evaluasi Pendidikan Edisi Revisi. Jakarta: Bumi Aksara.

Thiagarajan, S., Dorothy. S.S. and Melvyn, I.S. 1974. Instructional Development for Training Teachers of Excptional Children. Indiana: Center for innovation.

Vidal, R.V. 2010. "Creative Problem Solving". Journal of Operacional", No. 02, Vol. 30, pp. 405-426.

Wardahana, W.A. 2004. Dampak Pencemaran

n. Yogyakarta: Andi

$$
\text { Lingkunga }
$$


R E F O R M A J u r n a 1 P e n d i d i k a n \& P e m b e 1 a ja $\mathrm{r}$ a $n$ 